\title{
SISTEM KAPITALISME NEGARA SEBAGAI ALTERNATIF SISTEM EKONOMI KERAKYATAN BERDASARKAN PANCASILA
}

\author{
Itok Dwi Kurniawan ${ }^{1)}$, Sri Lahir ${ }^{2)}$ \\ 1) Prodi PPKn FKIP Universitas Sebelas Maret, Surakarta \\ Email: itokdwikurniawan@staff.uns.ac.id \\ 2) Sekolah Tinggi Ilmu Ekonomi AAS Surakarta \\ Email: srilahir@gmail.com
}

\begin{abstract}
Abstrak: Sistem ekonomi terus mengalami perkembangan. Salah satunya ada bentuk baru sistem ekonomi adalah sistem kapitalisme negara. Sistem kapitalisme negara tidak seperti sistem kapitalisme pada umumnya. Aktor utama sistem ini adalah negara yang didukung oleh perusahaan minyak negara, perusahaan negara, perusahaan swasta unggulan negara, dan dana kekayaan negara. Peluang sistem kapitalisme dijalankan di Indonesia sangatlah terbuka melalui sistem kerja sama antara negara dan swasta dalam pembangunan ekonomi. Penelitian ini bertujuan untuk melihat penerapan sistem kapitalisme negara yang ada di Indonesia. Metode dalam makalah ini menggunakan metode study literature, dengan memaparkan teori yang berhubungan dengan judul, yang diperoleh dari jurnal, buku dokumentasi, dan internet. Hasil Penelitian menunjukkan bahwa secara teoritis dan konstitusi, sistem kapitalisme negara bisa diterapkan di Indonesia dengan menafsirkan secara operasional asas kekeluargaan dan penguasaan cabang-cabang produksi yang penting bagi masyarakat umum oleh negara. Namun, dalam praktiknya, sebagaimana dijelaskan bahwa pendukung kapitalisme negara terdiri dari 4 faktor yaitu perusahaan minyak, perusahaan negara, perusahaan swasta unggulan negara, dan dana kekayaan negara; untuk Indonesia masih mengalami kesulitan menerapkannya.
\end{abstract}

\section{Kata Kunci: kapitalisme negara, sistem ekonomi Indonesia}

\begin{abstract}
Economic systems have continuously been developing. One of them is the new form of economic system, namely: state capitalism. State capitalism is unlike the capitalist system in general. The principal actor of this system is state, which is backed up by owned oil companies, state-owned enterprises, private companies favored by the state, and sovereign wealth funds. The state capitalism has a very great opportunity to be run in Indonesia through cooperation between the state and private parties in the economic development. This study aims to see the application of state capitalism system in Indonesia. The method in this paper uses the method of study literature, by describing the theory related to the title, obtained from journals, documentation books, and internet. The results of the study show that theoretically and constitutionally, the state capitalism system can be applied in Indonesia by interactively interpreting the principle of kinship and the controlling of production branches that are important to the general public by the state. However, in practice, as explained that the supporters of state capitalism consists of four factors, namely oil companies, state enterprises, state-owned private companies, and state wealth funds; for Indonesia is still having difficulty applying it.
\end{abstract}

Keywords: state capitalism, Indonesia economic system 


\section{PENDAHULUAN}

Salah satu penyebab runtuhnya Uni Soviet adalah sistem perekonomian komunisme berubah menjadi sistem perekonomian pasar. Perubahan struktural dalam sistem perekonomian Uni Soviet dimotori oleh Mikail Gorbachev. Keruntuhan komunisme di negara-negara Eropa Timur dan Soviet merupakan sebuah tikaman langsung ke jantung terhadap pandangan bahwa pemerintah dapat mengusahakan kesejahteraan nasional melalui mengelola perekonomian secara langsung dan aktif. Ketika Uni Soviet runtuh pada awal dekade 1990-an, jutaan orang banyak yang beralih dari pasar gelap ke pasar bebas.

Seraya melanjutkan kemenangan sistem perekonomian pasar, banyak pemerintah melakukan privatisasi terhadap asset-aset milik negara, seperti di Inggris, Brazil, dan Argentina. Sebagai dukungan terhadap kemenangan perekonomian pasar, Presiden Amerika Serikat, Ronal Reagan, dengan tegas menyatakan bahwa era pemerintahan yang gemuk sudah berakhir. Pemerintahan Inggris di bawah Margaret Thatcher menggelar kebijakan privatisasi bagi perusahaan-perusahaan milik negara yang tidak menguntungkan, terutama di bidang energi dan pembangkitan daya mineral, transportasi, serta telekomunikasi. Sejak saat itu pula, perekonomian di dunia beralih menjadi perekonomian pasar serta lebih mengglobal dan mengintegrasikan dirinya melalui pasar-pasar perdagangan, seperti NAFTA, AFTA, GATT/WTO, dan ASEAN + 3 .

Perekonomian pasar benar-benar membuat pertumbuhan ekonomi dunia naik dan ada fakta menarik juga: perdagangan membawa kesejahteraan dan mengentaskan kemiskinan, terutama di negara berkembang. Satu studi komprehensif yang paling sering dikutip tentang dampak perdagangan dilakukan oleh Jeffrey Sach dan Andrew Warner yang mengkaji kebijakan-kebijakan perdagangan di 117 negara antara 1970-1989. Dengan mengontrol beberapa faktor, studi tersebut mengungkapkan adanya hubungan signifikan secara statistik antara perdagangan bebas dan pertumbuhan yang tidak berhasil ditemukan oleh kedua penulis ini; contohnya antara pendidikan dan pertumbuhan. Pertumbuhan di negara yang menerapkan perdagangan bebas tercatat tiga sampai enam kali lebih tinggi daripada di negara proteksionis. Negara berkembang yang terbuka mencatat angka rerata pertumbuhan tahunan 4, 49 persen dalam dua dasawarsa terakhir, sedangkan negara berkembang tertutup hanya 0,69 persen. Negara industri yang terbuka mempunyai angka pertumbuhan tahun 2, 29 persen, sedangkan yang tertutup hanya 0,74 persen (Wu dan Lin dalam Soesastro, 2004).

Namun, korelasi antara sistem perdagangan bebas dan sistem usaha swasta (baca: kapital swasta) berhasil menumbuhkembangkan kekayaan swasta, investasi swasta, dan perusahaan swasta perlahan-lahan meredup. Pada tahun 2000, sebuah laporan yang dirilis oleh Institute for Policy Studies tertulis fakta-fakta: bahwa 51 di antara 100 mesin terbesar ekonomi adalah perusahaan, sedangkan 49 adalah negara (Klein, 1999: xxiii). General Motors telah menjadi lebih besar jika dibandingkan Denmark, Mitsubishi lebih besar jika dibandingkan Indonesia, dan Sony lebih besar jika dibandingkan Pakistan (Anderson dan Cavanagh dalam B. Herry Priyono, 2000). Situasi ini berbalik 180 derajat. Pada antara tahun 2004 - 2008, 117 perusahaan milik negara dan milik publik dari Brazil, Rusia, India, dan China muncul pertama kali dalam daftar perusahaan terbesar dunia Forbes Global 2000, yang diukur berdasarkan penjualan, laba, aset, dan nilai pasar (Bremmer, 2011: 13). 
Pertumbuhan pesat perusahaan negara juga diikuti krisis keuangan 2007/2008 di Amerika Serikat, jantungnya kapitalisme dunia. Mau tidak mau, pemerintah AS menyuntik penyertaan modalnya untuk perusahaan-perusahaan swasta besarnya, seperti Ford dan General Motors. Sejak saat itu, terjadilah apa yang disebut new economic hybrid atau percampuran antara pasar dan negara. Dalam bahasa yang lain, kita sedang menuju bangkitnya sistem perekonomian baru yaitu sistem kapitalisme negara. Artikel ini akan membahas persoalan-persoalan sebagai berikut: pendukung berlakunya sistem kapitalisme Negara dan bagaimana peluang berlangsungnya sistem kapitalisme negara di Indonesia

\section{KAJIAN TEORI}

\section{A. Sistem Kapitalisme}

Kapitalisme merupakan sebuah sistem organisasi ekonomi yang dicirikan oleh hak milik privat atas alat-alat produksi dan distribusi yang pemanfaatannya untuk mencapai laba dalam kondisi yang sangat kompetitif. Ada empat penyangga berlakunya sistem ekonomi kapitalisme yaitu sebagai berikut: pertama, kegiatan ekonomi dalam sisten kapitalisme digerakkan dan dikoordinasi oleh pasar bebas dengan instrumen harga sebagai penanda (sinyal). Jika harga dianggap melebihi biaya produksi dan margin laba, hal tersebut merupakan sinyal bagi pelaku ekonomi lain untuk masuk ke pasar menambah persediaan (supply) barang/jasa sehingga dapat menurunkan harga; demikian juga sebaliknya. Kedua, setiap individu memiliki kebebasan untuk mempunyai hak kepemilikan (property rights) sebagai dasar melakukan transaksi. Tanpa adanya hak kepemilikan, individu tidak akan pernah bisa mengeksekusi kegiatan ekonomi. Oleh karena itu, salah satu fungsi terpenting dari kapitalisme adalah menawarkan dan melindungi hak kepemilikan swasta. Ketiga, kegiatan ekonomi dipisahkan oleh tiga pemilik faktor produksi yakni pemodal, tenaga kerja, dan pemilik lahan. Pemilik modal memperoleh pendapatan dari laba, tenaga kerja dari upah, dan pemilik lahan dari sewa. Keempat, tidak ada halangan bagi pelaku ekonomi untuk masuk dan keluar pasar. Pelaku ekonomi yang melihat peluang profit bisa langsung pasar. Demikian pula pelaku ekonomi yang gagal (rugi) dapat langsung keluar tanpa ada regulasi yang menghambatnya (Ahmad Erani Yustika, 2012: 220).

\section{B. Sistem Kapitalisme Negara}

Sesuai dengan namanya, pelaku utama kapitalisme negara adalah pemerintah, bukan investor. Pemerintah memutuskan industri-industri apa, dan bahkan perusahaanperusahaan apa, yang perlu dikembangkan. Kebijakan ekonomi pemerintah mengarah untuk melaksanakan keputusan yang mendukung penggunaan-penggunaan berbagai alat kebijakan untuk mendukung industri-industri atau perusahaan-perusahaan "pemenang" yang telah dipilih. Sistem ekonomi ini tetap menganut mahzab kapitalisme karena pemerintah tetap mengakui dan menegakkan hak-hak kepemilikan atas properti dan kontrak, pasar mengarahkan harga barang dan jasa yang diproduksi, dan upah tenaga 
kerja yang dipekerjakan, dan beberapa kegiatan usaha berskala kecil tetap berada di tangan sektor swasta.

Berdasarkan penelusuran pustaka setidaknya ada tiga cara terkait penggunaan istilah kapitalisme negara. Pertama, kapitalisme negara berguna untuk menerangkan sistem saat pemerintah mengizinkan perusahaan-perusahaan milik swasta memonopoli sebuah sektor industri secara keseluruhan. Kedua, kapitalisme negara dapat menerangkan cara-cara ketika pemerintah secara resmi mengambil alih kendali atas perekonomian pasar selama masa perang. Banyak perusahaan terkemuka Jerman, Prancis, dan Inggris tetap di tangan swasta saat Perang Dunia II meletus. Akan tetapi, begitu konflik terjadi, pemerintah memaksakan masuk mengambil kebijakan perencanaan ekonomi terpusat secara menyeluruh. Ketiga, kapitalisme negara menerangkan kebijakan yang dilakukan oleh para pejabat publik pada saat terjadi sistem politik demokrasi pasar bebas supaya industri-industri tertentu tetap berada di tangan publik (Baumol. Dkk, 2010: 111). Contoh paling popular adalah kebijakan privatisasi di Inggris yang secara serentak menswastanisasi banyak perusahaan negara, seperti British Airways, British Gas, British Steel, British Telecom, dan British Petroleum. Namun, kebijakan privatisasi itu sama sekali tidak menyentuh National Health Service Inggris yang tetap menjadi perusahaan terbesar di Eropa dengan lebih dari 15 juta nama dalam daftar gajinya.

\section{Sistem Perekonomian Indonesia}

Sistem perekonomian Indonesia tidaklah menganut sistem kapitalisme maupun sosialisme. Sistem perekonomian Indonesia sampai saat ini masih menjadi perdebatan yang menarik. Dalam sejarah Indonesia, republik ini sudah ada 2 orde yang begitu jelas merumuskan sistem ekonominya yaitu Orde Lama dan Orde Baru.

1. Orde Lama

Pada masa Orde Lama, sistem perekonomian Indonesia menganut sebuah sistem yang disebut Sosialisme Indonesia. Sosialisme Indonesia memiliki pengertian suatu ajaran dan gerakan tata masyarakat adil dan makmur berdasarkan Pancasila. Masyarakat adil dan makmur berdasarkan Pancasila sebagai perwujudan sosialisme Indonesia bersendikan pokok keadilan, kerakyatan, dan kesejahteraan. Sosialisme Indonesia juga bertujuan mengakhiri dan melenyapkan segala penderitaan rakyat lahirbatin, serta memberikan nikmat rohaniah dan badaniah dengan menciptakan tata masyarakat dalam wadah negara Indonesia. Ciri pokok sosialisme Indonesia adalah perpaduan antara unsure sosialisme yaitu keadilan sosial dan kesejahteraan, serta kepribadian Indonesia yaitu kekeluargaan dan gotong-royong.

Pokok-pokok pemikiran ekonomi sosialisme Indonesia dapat dijelaskan sebagai berikut:

a. Segala produksi, baik yang diusahakan oleh negara maupun swasta harus ditujukan terhadap kepentingan rakyat, terutama kebutuhan pokok, hidup, agar setiap warga negara dapat hidup layak sebagai manusia merdeka.

b. Seluruh kegiatan distribusi diatur sedemikian rupa sehingga barang-barang keperluan hidup sehari-hari dapat sampai cepat merata, dan murah di tangan rakyat. 
c. Segala kegiatan pertanian dan industri dibawa ke tingkat ekspor Indonesia meningkat menjadi ekspor barang-barang jadi.

d. Segala kegiatan impor ditujukan terhadap barang-barang yang dapat menambah produksi barang dalam negeri.

e. Negara harus segera memulai dengan membangun industri, khusus industri dasar. Oleh karena, tanpa adanya industri dasar, semboyan untuk mencukupi keperluan sendiri merupakan semboyan yang tidak mungkin dilaksanakan.

2. Orde Baru

Orde Baru memiliki dokumen pembangunan yang jauh lebih sistematis dan terperinci dibandingkan Orde Lama. Dokumen pembangunan Orde Baru disebut Garis-Garis Besar Halauan Negara (GBHN). Setiap lima tahun diadakan penyesuaian terhadap GBHN agar sesuai dengan dinamika kehidupan masyarakat. Oleh karena itu, esensi sistem ekonomi pada masa Orde Baru hakikatnya tersurat dalam GBHN. GBHN bukan semata konsep pembangunan ekonomi, melainkan konsep pembangunan semua bidang kehidupan. Meskipun begitu, sepanjang pemerintah Orde Baru, bidang ekonomi merupakan prioritas utama pembangunan.

Demokrasi ekonomi dijadikan penuntun dalam pedoman penentuan kebijakankebijakan ekonomi. Demokrasi ekonomi dirumuskan dengan lebih jelas, serasi, serta seimbang antardaerah dalam satu kesatuan perekonomian nasional, dengan mendayagunakan potensi dan peran serta daerah secara oprimal dalam rangka perwujudan wawasan nusantara dan ketahanan nasional. Juga disebutkan bahwa dalam pelaksanaan demokrasi ekonomi harus dihindarkan hal-hal berikut:

a. Sistem free fight liberalism.

b. Sistem etatisme.

c. Persaingan tidak sehat serta pemusatan kekuasaan ekonomi di suatu kelompok dalam berbagai bentuk monopoli (pembeli tunggal) yang merugikan masyarakat dan bertentangan dengan cita-cita keadilan social.

\section{Eksperimen Sistem Kapitalisme Negara di Berbagai Negara}

1. Kapitalisme Negara di Jazirah Arab

Di Arab Saudi, kapitalisme negara skala besar merupakan suatu yang secara alami berkesesuaian dengan pemerintahan yang berkuasa. Keluarga Kerajaan Arab Saudi merupakan penguasa utama. Kekuatan utama kapitalisme negara di Arab Saudi adalah cadangan minyak yang melimpah. Pendapatan minyak berkontribusi sekitar satu per tiga PDB total negara tersebut. Perusahaan minyak terbesar di Arab Saudi sekaligus dunia, Aramco, dikuasai oleh negara. Meskipun Aramco dikuasai negara, tetapi anggaran dan operasi Aramco diawasi oleh Kementerian Perminyakan dan Sumber Daya Mineral. Salah satu kelebihan Aramco adalah negara, terutama keluarga kerajaan, tidak terlalu ikut campur dalam urusan bisnis Aramco. Keluarga kerajaan mengizinkan Aramco menyusun strategi komersial perusahaan dan mengendalikan operasi-operasinya. 
Selain Arab Saudi, negara di Timur Tengah yang menjalankan sistem kapitalisme negara adalah Uni Emirat Arab (UAE). Perbedaan utama antara Arab Saudi dan UAE dalam pelaksanaan sistem kapitalisme negara adalah tidak bergantung kepada minyak. UEA, terutama Dubai, telah bereksperimen dalam skala besar dengan investasi asing dan pasar terbuka, meskipun perkembangan masih digerakkan dan diarahkan oleh negara. Eksperimen kapitalisme negara ini terhenti pada tahun 2009 karena krisis keuangan global.

Perkembangan kapitalisme negara di UEA berpindah ke investasi dana-dana di luar negeri, yang dilakukan oleh lembaga dana kekayaan negara, seperti Abu Dhabi Invesment Council, International Petroleum Invesment Company. Lembaga dana kekayaan negara yang dikelola secara tidak transparan ini, kemudian diketahui membeli sebagian besar saham-saham lembaga keuangan dunia, seperti Citigroup, HSBC, dan Sony. Di UAE, meskipun berkembang industri keuangannya, tetapi tidak memiliki perusahaan swasta unggulan negara. Semua perusahaan swasta terhubung erat dengan para emirat yang mengedepankan bisnis keluarga. Perusahaan swasta negara di UEA menjadi pundi-pundi kekayaan para emirat, bukan untuk menaikkan posisi tawar negara tersebut di politik dunia.

2. Kapitalisme Negara di Asia Tenggara

Di Asia Tenggara, ada beberapa negara yang mempraktikkan unsur-unsur kapitalisme negara. Pertama, Indonesia pada saat dipimpin oleh Presiden Soeharto selama 32 tahun yang menghasilkan puluhan perusahaan negara. Presiden Soeharto menyetujui setiap pembentukan bank-bank, perusahaan listrik, perusahaan utilitas, dan perusahaan telekomunikasi, serta tidak kalah pentingnya adalah suatu jaringan kompleks perusahaan-perusahaan swasta yang saling terhubung secara politik di bidang perkayuan, perminyakan, gas, pertambangan, tekstil, rokok, dan pertanian. Selain itu, konglomerat Indonesia banyak yang mengandalkan kedekatan pribadi dengan pejabat politik yang berkuasa untuk menghalangi reformasi pasar yang akan membebani mereka dengan persaingan murni.

Kedua, Vietnam yang secara resmi masih ingin beraliran komunis. Namun, Vietnam meluncurkan sebuah program reformasi ekonomi yang disebut doi moi atau renovasi untuk menggerakkan sistem perekonomian terpimpin ke sistem kapitalisme negara. Sasaran sistem doi moi adalah memperkuat kekuasaan politik negara dengan memberdayakan sektor swasta untuk merangsang pertumbuhan ekonomi di beberapa sektor sambil mempertahankan pengendalian yang ketat atas lainnya.

Ketiga, Malaysia yang selama 40 tahun telah menggunakan kapitalisme negara untuk melayani kepentingan politik pemerintah negara tersebut. Aktor utama sistem kapitalisme negara di Malaysia adalah perusahaan minyak dan gas nasional mereka, Petronas. Perusahaan nasional ini berinvestasi lebih di 30 negara. Petronas juga memegang peranan penting ketika menyelamatkan perusahaan negara Malaysia yang mengalami kesulitan likuiditas pada saat terjadi krisis keuangan global 2008/2009. 


\section{RUANG LINGKUP DAN METODE PENELITIAN}

Ruang lingkup penelitian ini ingin mengetahui keberlakuan sistem kapitalisme negara jika diterapkan di negara Indonesia. Sistem kapitalisme negara merupakan varian sistem kapitalisme yang memprioritaskan negara sebagai aktor utama dalam kegiatan perekonomian. Hal ini menarik diteliti karena Pasal 33 Undang-Undang Dasar Negara Republik Indonesia Tahun 1945 memberikan tempat yang seimbang kepada negara dan swasta sebagai pemain dalam perekonomian Indonesia. Situasi yang seimbang ini memungkinkan adanya kerja sama antara negara dan swasta dalam menjalankan perekonomian.

Metode dalam makalah ini menggunakan metode study literature, dengan memaparkan teori yang berhubungan dengan judul, yang diperoleh dari jurnal, buku dokumentasi, dan internet.

\section{PEMBAHASAN}

\section{A. Pendukung Berlakunya Sistem Kapitalisme Negara}

Untuk mengelola kapitalisme negara, pemimpin-pemimpin politik menggunakan bermacam-macam lembaga yang berfungsi sebagai kepanjangan tangan. Negara tidak selalu menjalankan kendali sehari-harinya, tetapi ia memiliki pengaruh yang cukup langsung terhadap alat-alat itu. Lembaga-lembaga tersebut adalah perusahaan minyak dan gas, badan-badan usaha milik negara, badan-badan usaha swasta yang diunggulkan oleh pemerintah, dan lembaga dana kekayaan negara.

1. Perusahaan minyak dan gas nasional

Perusahaan negara-negara di seluruh dunia, terutama mereka yang mengimpor minyak dan gas, telah mulai menginvestasikan dana yang cukup besar dalam mengembangkan sumber-sumber energi pengganti energi hidrokarbon. Namun, karena berbagai alasan, minyak dan gas masih akan menggerakkan perekonomian dunia untuk sekian tahun lagi. Banyak pakar industri mengharapkan produksi minyak dunia memuncak sebelum tahun 2030. mereka juga memiliki taksiran bahwa antara 1,2 dan 1,3 triliun barel cadangan yang entah terbukti atau berpeluang terbukti akan tetap ditemukan, dua pertiganya ada di Timur Tengah (Friedmann, 2011: 40).

Pertumbuhan ekonomi yang cepat di negara China dan India menyebabkan konsumsi akan minyak naik secara astronomis. Para pakar memperkirakan bahwa penduduk di dunia menggunakan hampir 86 juta barel per hari (Friedman, 2011: 50). Pihak yang paling diuntungkan dari lonjakan konsumsi minyak dunia adalah perusahaan-perusahaan multinasional Barat, seperti ExxonMobil, Royal Dutch Shell, dan British Petroleum. Meskipun demikian, kenyataannya yang menguasai tiga perempat cadangan minyak mentah di dunia adalah perusahaan-perusahaan minyak nasional, seperti Saudi Aramco, Gazprom di Rusia, Abu Dhabi National Oil Company, Kuwait Petroleum Corporation, CNPC di China, NIOC di Iran, Petronas di Malaysia, dan Petrobras di Brazil.

Raksasa-raksasa minyak milik negara ini merupakan perusahaan-perusahaan energi paling besar apabila diukur menurut cadangan yang dikuasainya. Sebaliknya, 
perusahaan-perusahaan multinasional secara bersama-sama hanya menghasilkan 10 persen minyak dan gas dunia. Perusahaan-perusahaan multinasional tersebut juga menguasai kira-kira tiga persen cadangannya. Perusahaan multinasional terbesar yaitu ExxonMobil hanya menduduki peringkat ke-15 di dunia. Adapun 14 perusahaan energi milik negara paling besar memegang kendali atas dua puluh kali lebih banyak minyak dan gas dibandingkan delapan perusahaan multinasional terbesar (Bremmer, 2010: 60 $-61)$.

Ada perbedaan-perbedaan mencolok antara perusahaan minyak nasional dan multinasional. Perusahaan minyak nasional sebagian besar merupakan hasil kebijakan nasionalisasi terhadap sisa-sisa industri minyak yang pernah dikembangkan oleh perusahaan-perusahaan multinasional beberapa dasarwarsa silam, sedangkan yang lain adalah perusahaan-perusahaan yang didirikan setelah zaman penjajahan berlalu. Tidak semua perusahaan itu dimiliki oleh negara secara penuh. Sebagian mempunyai kemampuan teknik jauh lebih tinggi daripada yang lain. Kemandirian mereka dalam operasional sangat bervariasi, tetapi tidak satu pun kebal sepenuhnya terhadap campur tangan politik.

Sebagai contoh PDVSA di Venezuela yang sangat direcoki oleh negara dalam pengelolaannya. PDVSA menyumbang satu pertiga PDB negara tersebut dan memiliki karyawan terbanyak. Pada tahun 2002, hampir setengah karyawan PDVSA melakukan aksi mogok untuk menolak keputusan Hugo Chaves untuk mengangkat dewan direksi perusahaan yang akan memberinya kendali lebih besar terhadap operasi-operasi perusahaan itu. Chaves menanggapi aksi mogok itu dengan memecat sekitar 18 ribu pekerjanya, termasuk beberapa insinyurnya yang paling berbakat dan berpengalaman. Pada tahun 2006 dan 2007, pemerintahan Chaves berhasil memperoleh kendali terbesar atas ladang-ladang yang sebelumnya mengelolanya dengan cara patungan bersama pihak asing. Kawasan ladang-ladang itu berada di daerah yang disebut Sabuk Orinoco dan merebut asset-aset dari beberapa perusahaan minyak internasional. Saham rata-rata PDVSA dalam industri minyak Venezuela melonjak 80 persen. Meskipun nilai sahamnya melonjak, ambisi politik Chaves yang begitu besar membutuhkan biaya yang tidak sedikit. Chaves mengenakan pajak royalti yang sedemikian tingginya terhadap PDVSA untuk mendanai pengeluaran-pengeluaran politiknya. Pada tahun 2006-2007, tagihan PDVSA naik menjadi 16 persen ketika pendapatannya turun sebanyak tiga persen. Pemerintah juga menuntut PDVSA membiayai program-program populistik Chaves, seperti peningkatan infrastruktur listrik, pembangunan perkotaan, serta pembiayaan untuk membeli dan membagikan makanan kepada masyarakat miskin (Bremmer, 2011: 65).

Meskipun demikian, ada juga perusahaan minyak nasional yang relatif kebal dari tekanan politik. Mereka memiliki banyak manajer-manajer yang profesional, pengalaman, dan otonomi operasional untuk bersaing secara sehat dengan perusahaan multinasional. Contohnya Petrobras di Brasil, Petronas di Malaysia, dan Sonatrach di Aljazair. Kebebasan yang diperoleh ketiga bisa-bisa PDVSA akan iri. Kebebasan itu memperbolehkan manajemen membuat sebagian besar keputusan strategisnya sendiri 
dan menginvestasikan kembali bagian dengan persentase yang sehat dari laba yang diperoleh. Seperti yang terjadi di Sonatrach, sejak didirikan pada tahun 1963 sebagai hasil nasionalisasi asset-aset perusahaan minyak yang sebagian besar milik Prancis. Mereka memulai bisnisnya bermodel kerja sama dengan perusahaan minyak asing yang beroperasi di negara tersebut. Pada tahun 2006, undang-ndang Aljazair menetapkan bahwa Sonatrach harus memiliki sedikitnya 51 persen saham di sektor hulu, jaringan pipa, dan proyek-proyek penyulingan, tetapi pemerintah cenderung membiarkan manajer-manajer perusahaan mengembangkan bisnis untuk mendapatkan uang sendiri tidak hanya melalui kenaikan pajak dan royalti dari operator-operator asing.

2. Badan-badan usaha milik negara

Badan-badan usaha milik negara merambah ke luar sektor energi. Perusahaanperusahaan ini tidak semata-mata dapat disebut sisa peninggalan komunisme atau bahkan demokrasi sosial Eropa pascaperang. Setiap satuan ekonomi besar di dunia memiliki setidaknya badan usaha milik negara. Perusahaan-perusahaan negara yang mendominasi industri-industri secara keseluruhan berfungsi untuk meningkatkan kekuasaan politik.

Banyak negara di dunia menggunakan perusahaan negara sebagai sarana untuk mengamankan sumber daya alamnya agar tidak jatuh kepada korporasi atau negara asing. Perusahaan negara memiliki keunggulan kompetitif yang tidak sedikit. Mereka memiliki dukungan langsung dari pejabat-pejabat di pemerintah, yang dapat menawarkan insentif-insentif politik dan keuangan yang menarik terhadap perusahaan asing yang akan mereka dekati. Mereka dapat bekerja sama dengan perusahaan nasional lainnya, khususnya di negara-negara yang membatasi keterlibatan perusahaan-perusahaan multinasional di bidang sumber daya alam.

Selain itu, perusahaan negara masih mempunyai keunggulan lain. Mereka mampu berinvestasi dalam kemitraan skala besar dengan rezim-rezim represif yang tidak dapat didekati oleh perusahaan-perusahaan multinasional. Perusahaan negara dapat melakukan hal tersebut karena mereka dapat membatasi liputan pers yang memublikasikan reputasi perusahaan negara dan/atau rezim yang diajak bekerja sama.

Pendirian perusahaan negara ditujukan agar sasaran dan kepentingan politik dapat terpenuhi anggarannya. Perusahaan negara juga dapat mengamankan akses jangka panjang ke pasokan sumber daya yang berlimpah. Tujuan pendirian perusahaan negara bukan untuk perolehan laba, melainkan terpenuhinya ambisi-ambisi politik negara tersebut. Ambisi itu bisa seperti mengamankan dan mengeksploitasi sumber daya alam yang tidak berani dilakukan oleh perusahaan swasta multinasional karena pertimbangan biaya-biaya yang cukup besar.

3. Badan-badan usaha swasta yang diunggulkan pemerintah

Perusahaan swasta unggulan pemerintah pada dasarnya tetap perusahaan yang dimiliki oleh swasta; meskipun pemerintah juga turut serta andil dalam porsi minoritas besar. Perusahaan jenis ini mengandakan dukungan pemerintah secara agresif untuk meraih posisi pengendali dalam perekonomian dalam negeri dan di pasar-pasar 
ekspornya. Keuntungan perusahaan swasta unggulan pemerintah adalah sering mendapat perlakuan istimewa dalam lelang-lelang pekerjaan yang penyelenggaranya negara. Selain itu, mereka akan mendapat fasilitas pinjaman lunak dari bank negara, cuti pajak, dan paling penting adalah monopoli.

Banyak perusahaan multinasional yang berkantor di New York bahkan London, dan kita mengiranya itu benar-benar perusahaan nasional tanpa embel-embel negara. Akan tetapi, perkiraan kita salah karena mereka mendapatkan dukungan besar dari pemerintah; meskipun hanya berupa saham minoritas besar atau golden share. Dengan berkantor di mancanegara, mereka akan berebut kontrak-kontrak kerja yang mungkin juga bisa mendapatkannya dengan bantuan diplomasi asal negara tersebut.

4. Lembaga dana kekayaan negara

Dana kekayaan negara merupakan kelebihan dana tunai di bawah pengelolaan negara yang dapat diinvestasikan secara strategis. Pemerintah dapat menggunakan laba yang dihasilkan untuk kepentingan-kepentingan politik. Mereka juga dapat menggunakan dana itu sendiri untuk membeli saham-saham di perusahaan dan lembaga-lembaga yang memiliki nilai strategis, terutama di luar negeri. Dana seperti ini antara lain diadakan oleh pemerintah-pemerintah yang tidak mempraktikkan kapitalisme negara. Maka sekali lagi, bukan alat menjadi masalah melainkan cara penggunaannya.

Dana kekayaan negara bersumber dari tiga hal. Pertama, devisa yang didapatkan dari ekspor sumber daya alam, terutama minyak dan gas alam, yang merupakan sumber utama pendapatan negara Rusia, Arab di Teluk Persia, dan beberapa negara Afrika Utara. Kedua, dana tunai ekstra yang tersisa dari negara perdagangan positif. Sebagai contoh, Cina menghimpun dana kekayaan negara dengan devisa yang didapatkan melalui ekspor besar-besaran barang-barang manufaktur ke Amerika Serikat, Eropa, dan Jepang. Uang untuk dana itu juga bisa berasal dari laba yang dihasilkan oleh badan-badan usaha milik negara, dana dari privatisasi, dari uang lebih ketika pengeluaran pemerintah lebih kecil dibandingkan pajak yang masuk, atau melalui transfer dari rancangan dana pension yang diselenggarakan oleh pemerintah. Ketiga, dana kekayaan negara yang kadang-kadang didukung melalui transfer langsung dan sekaligus dari anggaran pemerintah atau cadangan devisa.

Dana-dana ini umumnya meliputi sejumlah aset keuangan dalam portofolio dengan tingkat risiko yang bermacam-macam: devisa, saham, surat berharga pemerintah dan korporasi, logam mulia, real estate, dan aset-aset lain. Dana itu dipergunakan untuk membeli saham di perusahaan (terkadang kepemilikannya mayoritas) dalam dan luar negeri, termasuk hedge funds dan leveraged buyouts, perusahaan yang khusus menyediakan pinjaman untuk membiayai pembelian saham. Yang membuat dana-dana itu berbeda dan menghadirkan tantangan bagi pasar bebas adalah bahwa yang mengelola investasi-investasi dana itu tidak bertanggung jawab kepada para pemegang saham. Lembaga dana kekayaan negara memiliki satu pemegang saham yaitu pemerintah pusat. 


\section{B. Peluang Berlangsungnya Sistem Kapitalisme Negara di Indonesia}

Jika kita melihat uraian di atas, terlihat bahwa kapitalisme negara didukung oleh negara dengan pemanfaatan kekayaan alam dan dana-dana lebih dihasilkan karena boom minyak atau surplus ekspor. Apakah sistem kapitalisme negara memiliki peluang diterapkan di Indonesia? Apabila melihat dari sistem ekonomi yang pernah berjalan di Indonesia yaitu sistem sosialisme negara dan sistem GBHN, penulis melihat ada peluang menerapkan sistem kapitalisme negara.

Hal ini dilandasi, pertama, sistem sosialisme pada hakikatnya adalah kapitalisme negara. Hal ini dikemukakan oleh Wilhelm Liebknechct dan Ludwig von Mises. Dalam sebuah pamfletnya, von Mises menjelaskan bahwa label kapitalisme negara merupakan label usang yang hanya merupakan pengganti dan tidak dapat menyelesaikan masalah dasar sosialisme itu sendiri.

Kedua, adalah konstitusi ekonomi bangsa Indonesia yang tercantum dengan jelas di Pasal 33 UUD 1945. Pasal ini setelah diamendemen berbunyi:

(1) Perekonomian disusun sebagai usaha bersama berdasar atas asas kekeluargaan.

(2) Cabang-cabang produksi yang penting bagi negara dan yang menguasai hajat hidup orang banyak dikuasai oleh negara.

(3) Bumi dan air dan kekayaan alam yang terkandung di dalamnya dikuasai oleh negara dan dipergunakan untuk sebesar-besar kemakmuran rakyat.

(4) Perekonomian nasional diselenggarakan berdasar atas demokrasi ekonomi dengan prinsip kebersamaan, efisiensi berkeadilan, berkelanjutan, berwawasan lingkungan, kemandirian, serta dengan menjaga keseimbangan kemajuan dan kesatuan ekonomi nasional.

(5) Ketentuan lebih lanjut mengenai pelaksanaan pasal ini diatur dalam UndangUndang.

Jika kita mencermati Pasal 33 Ayat (1) UUD 1945 terlihat bahwa sistem perekonomian Indonesia menganut asas kekeluargaan. Asas ini dapat dipandang sebagai asas bersama (kolektif) yang bermakna dalam konteks sekarang yaitu persaudaraan, humanisme, dan kemanusiaan. Artinya, ekonomi tidak dipandang sebagai wujud sistem persaingan liberal ala Barat, tetapi ada nuansa moral dan kebersamaannya, sebagai refleksi dari tanggung jawab sosial. Bentuk yang ideal terlihat seperti wujud sistem ekonomi pasar sosial (the social market economy), yang cukup berkembang di negaranegara Eropa Barat dan Skandinavia.

Rahardjo dan Herdianto dalam Munawar Ismail (2015: 42 - 43) menyatakan asas kekeluargaan adalah keinsafan, kesadaran, dan tekad untuk mengerjakan segala sesuatu oleh semua dan untuk semua di bawah pimpinan seseorang kepala dan di bawah pemilikan para anggotanya. Jika kita menafsirkan pengertian tersebut, kita tidak bisa serta-merta menyatakan bahwa asas kekeluargaan merupakan titik tengah antara sistem perencanaan sentralistik dan sistem koordinasi melalui pasar. Di satu sisi, mekanisme pasar memang mampu mengoordinasi ekonomi secara efisien, namun mekanisme harga ini cenderung meningkatkan konsentrasi pendapatan dan pemilikan asset di satu kelompok masyarakat tertentu. Namun, asas kekeluargaan di sini memberikan syarat 
bahwa mekanisme harga harus berjalan dengan prasyarat efisiensi, keuntungan, dan keadilan. Makna keadilan di sini adalah memberikan jaminan transaksi yang bebas kecurangan, diskriminasi, dan kerusakan, baik di bidang ekonomi, lingkungan, dan nilainilai masyarakat.

Ketiga, dalam perekonomian Indonesia peranan negara masih sangat penting. Peran negara difokuskan untuk membentuk kerangka kelembagaan yang dapat mengatur kegiatan ekonomi, hak kepemilikan, penegakan, dan eksekusi hukum yang menghasilkan biaya transaksi. Dengan demikian, peran negara bisa dibagi dalam empat klasifikasi yaitu stabilisasi makro ekonomi, mengoreksi kegagalan pasar, meredistribusi pendapatan, dan mengarahkan proses penyatuan ekonomi. Di Indonesia, peran negara di perekonomian masih ditambah dengan bisnis. Indonesia merupakan salah satu negara yang memiliki banyak perusahaan negara.

Berdasarkan ketiga landasan dan alat-alat pendukung berlangsungnya kapitalisme negara. Negara Indonesia setidaknya memiliki dua di antara empat hal yaitu perusahaan minyak dan perusahaan negara.

Perusahaan minyak di Indonesia, salah satunya adalah Pertamina. Di Indonesia, Minyak dan Gas Bumi sebagai sumber daya alam strategis tak terbarukan yang terkandung di dalam Wilayah Hukum Pertambangan Indonesia merupakan kekayaan nasional yang dikuasai oleh negara (Syeirazi, 2009: 100). Penguasaan oleh negara diselenggarakan oleh Pemerintah sebagai pemegang Kuasa Pertambangan. Setelah Badan Pengatur Migas dihapus keberadaannya oleh putusan Mahkamah Konstitusi dan digantikan SKK Migas, otomatis Pertamina memegang posisi kuasa pertambangan. Akan tetapi, pengelolaan perminyakan yang relatif tidak benar di masa lalu menyebabkan Pertamina tidak bisa tumbuh menjadi perusahaan minyak kelas dunia. Pertamina menjadi subjek politik dan tidak menjadi subjek bisnis sehingga hanya menjadi sapi perahan perahan para pemimpin politik.

Kedua, perusahaan negara. Sebagai kelompok, perusahaan-perusahaan negara merupakan konglomerasi bisnis paling raksasa, dengan penguasaan modal domestik terbesar dalam sistem ekonomi Indonesia. Dengan jumlah lebih dari 200 perusahaan, kegiatannya dari yang paling sederhana sampai paling rumit. Sebagian besar usaha mereka terpusat pada pelayanan publik (penerbangan, peralatan, konstruksi), pertambangan (minyak, gas, timah), keuangan dan perbankan serta industri manufaktur dasar. Dilihat dari ukuran dan pengaruhnya, praktik perusahaan negara lebih mengarah kepada istilah "negara dalam negara" (Nugroho dan Wrahatnala, 2000: 100).

Meskipun demikian, kita juga perlu membuka mata bahwa perusahaan yang mendapatkan untung besar di Indonesia (menurut Forbes 2014) sebagian besar BUMN yaitu BRI, Pertamina, Bank Mandiri, Bank BNI, PT Semen Indonesia, PT Perusahaan Gas Negara, dan PT Telkom. Untuk membuat BUMN menjadi efisien harus dilakukan restrukturisasi dan privatisasi.

Bagaimana dengan badan usaha swasta yang diunggulkan pemerintah dan lembaga dana kekayaan negara (souverenity fund)? Badan usaha swasta yang menjadi unggulan negara merupakan perusahaan negara yang dibina oleh pemerintah. Dibina, artinya 
pemerintah memajukan dan menciptakan mereka menghadapi pembatasan-pembatasan legal dan politik. Perusahaan swasta ini rata-rata memiliki hubungan yang baik dengan pemerintah. Pada zaman dahulu, di Indonesia banyak sekali perusahaan keuangan, khususnya perbankan, memiliki hubungan baik dengan pemerintah. Bank-bank tersebut memiliki kebebasan untuk mendirikan cabang dan menyalurkan kredit di perusahaan yang masih memiliki afiliasi dengan bank tersebut. Perusahaan swasta ini biasanya mendapatkan dukungan dari pemerintah untuk berebut proyek-proyek besar. Dukungan pemerintah ini bisa berupa suntikan modal dan lisensi untuk berkembang dan bersaing dengan perusahaan swasta lainnya. Di Indonesia, perusahaan yang seperti ini jumlahnya banyak sekali. Hubungan yang akrab antara para konglomerat dan pemerintah sudah terjadi sejak zaman dahulu, terutama zaman Orde Baru. Banyak sekali perusahaan swasta yang mendapatkan keistimewaan dari pemerintah. Namun, perusahaan swasta banyak yang menyalahgunakan berbagai fasilitas sehingga mendorong perusahaan tersebut ke jurang kebangkrutan dan juga menyebabkan Indonesia terjerembab dalam krisis ekonomi pada tahun 1997/1998.

Sekarang ini, dalam rangka perbaikan perekonomian. Pemerintah ingin memberlakukan prinsip persaingan usaha yang sehat dan adil bagi semua pihak, tak terkecuali perusahaan swasta. Dalam rangka menciptakan sistem persaingan yang sehat dan adil, pemerintah memberlakukan prinsip corporate governance bagi setiap perusahaan, baik swasta maupun negara. Situasi yang seperti ini menyulitkan berkembangnya perusahaan swasta meskipun akan berdampak baik, yaitu terciptanya persaingan yang sehat. Hal yang bisa dilakukan oleh pemerintah Indonesia adalah memilih perusahaan swasta yang akan diunggulkan. Pemerintah bisa menggunakan kriteria: perusahaan tersebut memiliki corporate governance yang baik dan perusahaan swasta tersebut bereputasi baik di luar negeri. Setidaknya ini yang harus dilakukan pemerintah jika ingin memiliki perusahaan swasta unggulan. Di China, Lenovo dan Huawei (telekomumikasi) dan AVIC (penerbangan) sudah menjadi perusahaan raksasa di negara tersebut. Di Korea Selatan, ada Samsung dan Hyundai. Bagaimana dengan Indonesia? Ada XL Axiata, Indofood (Indomie), dan Gajah Tunggal (ban), yang disebut dua terakhir bisa mewakili Indonesia di luar negeri.

Dana kekayaan negara di Indonesia tampaknya masih jauh panggang dari api. Meskipun sekarang usaha panggang itu telah berjalan, salah satunya adalah pengurangan subsidi BBM yang selama ini memberatkan APBN. Api pengurangan subsidi kepada pembentukan lembaga dana kekayaan negara dalam kondisi harga minyak yang rendah tidak bisa berkobar. Salah satu penyokong lembaga dana kekayaan negara adalah dana minyak dan ekspor komoditas. Negara Indonesia pernah menjadi negara kaya minyak yang kemudian mengalami boom minyak, namun tidak bisa memanfaatkannya. Dana minyak itu akhirnya menguap percuma. Harga komoditas di pasaran dunia pun cenderung berubah-ubah. Hal ini pastinya tidak menguntungkan negara Indonesia yang komoditas ekspornya masih produk primer, belum produk olahan. Jika Indonesia mampu memberikan nilai tambah, bukan tidak mungkin komoditas tersebut mampu menjadi penyumbang terbesar komposisi lembaga dana kekayaan negara. 
Kesimpulan tumbuhnya faktor lain sebagai pendukung kapitalisme negara juga bisa bermula dari dua faktor tersebut yaitu perusahaan minyak dan perusahaan negara. Perusahaan minyak yang profit tentunya dapat berkontribusi besar terhadap PDB bangsa, bahkan bisa memulai pembentukan oil fund yang bisa diinvestasikan sebagaimana negara penganut kapitalisme negara menyebarkan dana kekayaan negara. BUMN yang profit dan lama-kelamaan tidak lagi menjadi industri strategis bisa diprivatisasi dengan kepemilikan minoritas pemerintah.

\section{Sistem Ekonomi Kapitalisme Negara sebagai Alternatif Sistem Ekonomi Kerakyatan}

Sistem ekonomi kapitalisme negara bisa diterapkan sebagai alternatif sistem ekonomi kerakyatan. Perbedaan pokoknya ada dalam titik tekan sistemnya, yaitu negara sebagai komponen utama sistem kapitalisme negara dan rakyat sebagai komponen utama sistem ekonomi kerakyatan. Namun, tujuan utamanya sama adalah kesejahteraan rakyat. Selain itu, sistem ekonomi kerakyatan merupakan sistem ekonomi yang sering dipersamakan dengan sistem ekonomi Pancasila, artinya sistem ekonomi kerakyatan ini merupakan cita-cita negara Indonesia.

Karena itu, agar sistem ekonomi kapitalisme negara dapat berjalan seiring dengan sistem ekonomi kerakyatan harus ada perubahan watak sistem ekonomi tersebut. Perubahan watak itu meliputi setidaknya dua prasyarat. Prasyarat pertama, watak sistem kapitalisme negara haruslah demokratis. Sifat demokratis ini bersendikan nilai kerakyatan. Kebijakan ekonomi harus ditujukan demi peningkatan kesejahteraan rakyat. Sistem kapitalisme pada dasarnya mencerminkan sifat demokratis karena dalam sistem kapitalisme memungkinkan seorang/badan usaha berbisnis secara bebas. Setiap orang memiliki kebebasan untuk berusaha/berbisnis dalam rangka meningkatkan kesejahteraan/memperkaya diri. Hal ini sudah sesuai dengan cita-cita sistem ekonomi kerakyatan yang berprinsipkan pada demokrasi ekonomi: usaha dari rakyat, untuk rakyat, dan oleh rakyat. Sistem kapitalisme negara bisa berjalan dengan baik dalam rumpun demokrasi ekonomi jika menempatkan negara sebagai wasit yang adil. Sistem ekonomi kapitalisme tanpa negara yang ada ciri-ciri buruknya semata, seperti modal yang besar berkuasa, yang berani bersaing harus punya modal, yang bisa memengaruhi hukum/regulasi bisnis adalah orang-orang yang memiliki modal. Selain itu, silakan minggir saja. Negara bisa menengahi hal tersebut dengan duduk bersama dengan membuat peraturan yang adil atau menjadi wasit yang adil. Negara bisa menjadi pemandu kegiatan bisnis. Seluruh kegiatan bisnis meskipun berjalan dalam sistem ekonomi kapitalisme yang pro-pasar, negara dapat menjadi sarana koreksi apabila terjadi kegagalan pasar. Pada umumnya, kegagalan pasar itu dalam hal penyediaan barang/jasa yang dibutuhkan oleh masyarakat banyak, seperti sembako, pendidikan, dan kesehatan.

Kedua, prasyarat ini melanjutkan prasyarat pertama: negara harus sesegera mungkin menentukan usaha yang hanya boleh dikelola negara, dikelola negara dan swasta secara bersamaan, dan dikelola swasta saja. Yang dikelola swasta ini harus dipikirkan besar kecilnya usaha tersebut agar tidak bertabrakan dengan prinsip 
kerakyatan. Negara Indonesia sudah mengaturnya dalam Pasal 33 Ayat (2) Cabangcabang produksi yang penting bagi negara dan yang menguasai hajat hidup orang banyak dikuasai oleh negara dan Ayat (3) Bumi dan air dan kekayaan alam yang terkandung di dalamnya dikuasai oleh negara dan dipergunakan untuk sebesar-besar kemakmuran rakyat. Pengaturan tersebut masihlah bersifat umum, perlu pengaturan yang lebih khusus. Untuk usaha kecil, misalnya UKM dan UMKM, dapat dibuatkan aturan yang sedikit protektif, artinya negara, melalui lembaga di bawahnya, seperti Badan Koordinasi Penanaman Modal, Dinas Penanaman Modal dan Perindustrian di tingkat provinsi/kabupaten bisa membuat aturan yang lebih spesifik. Spesifik di sini, tidak hanya jenis peraturannya, Peraturan Kepala BPKPM, Perdaprov, Pergub, dan Perda, tetapi juga tingkat permodalannya dan usaha tersebut hanya boleh dikelola oleh UKM/UMKM.

\section{SIMPULAN}

Secara teoritis dan konstitusi, sistem kapitalisme negara bisa diterapkan di Indonesia dengan menafsirkan secara operasional asas kekeluargaan dan penguasaan cabang-cabang produksi yang penting bagi masyarakat umum oleh negara. Namun, dalam praktiknya, sebagaimana dijelaskan bahwa pendukung kapitalisme negara terdiri dari 4 faktor yaitu perusahaan minyak, perusahaan negara, perusahaan swasta unggulan negara, dan dana kekayaan negara; untuk Indonesia masih mengalami kesulitan menerapkannya. Meskipun diembel-embeli negara, perusahaan minyak dan perusahan negara haruslah mendapat keuntungan sebesar-besarnya. Baru-baru ini saja, pemerintah menyadari bahwa BUMN harus mulai melupakan ambisi politik dan berubah menjadi ambisi bisnis yaitu mencetak laba sebesar-besarnya. Situasi penciptaan BUMN yang profit oriented baru diciptakan pemerintah setelah berlakunya UU BUMN pada tahun 2003.

\section{SARAN}

Perlu segera diamendemen UU Nomor 22 Tahun 2001 tentang Minyak dan Gas Bumi dan UU yang berkaitan dengan sumber daya alam agar kekayaan negara tidak jatuh ke negara asing. Oleh karena itu, perusahaan negara yang berkaitan dengan minyak dan SDA haruslah dinomorsatukan agar bisa menjadi pemain utama bahkan operator kebijakan, tidak sekadar menjadi penonton. Selain itu, harus pula ada pengawasan bahwa kinerja perusahaan tersebut tidak menyimpang dari good governance dan sebisa mungkin lepas dari campur tangan pemerintah dalam keputusan-keputusan bisnisnya.

\section{DAFTAR PUSTAKA}

Ahmad Erani Yustika. 2014. Ekonomi Kelembagaan: Paradigma, Teori, dan Kebijakan. Jakarta: Erlangga

B. Herry Priyono. 2000. Neoliberalisme dan Kebebasan. Surakarta: Perpustakaan Insan Cendekia Wisma Mahasiswa.

Ian Bremmer. 2011. Akhir Pasar Bebas. Jakarta: PT Gramedia Pustaka Utama

M. Kholid Syeirazi. 2009. Di Bawah Bendera Asing: Liberalisasi Industri Migas di Indonesia. Jakarta: LP3ES

Munawar Ismail, et al. 2015. Sistem Ekonomi Indonesia. Jakarta: Erlangga 
Naomi Klein. 1999. No Logo. Jakarta: PT Dian Rakyat

Riant Nugroho dan Randy R. Wrahatnolo. 2008. Manajemen Privatisasi BUMN. Jakarta: Elex Media Komputindo

Soesastro, Hadi. 2004. Penanaman Modal dan Alih Teknologi. 75 Tahun Suhadi Mangkusuwondo: Tantangan Ekonomi Indonesia. Jakarta: Penerbitan CSIS

Thomas L. Friedmann. 2011. Hot, Flat, and Crowded. Jakarta: PT Gramedia Pustaka Utama

William Baumol, et al. 2010. Good Capitalism, Bad Capitalism. Jakarta: Gramedia Pustaka Utama dan Ciputra University 